\title{
A Case of Intrathyroidal Parathyroid Carcinoma Accompanied by Contralateral Parathyroid Hyperplasia
}

\author{
Beom Mo Koo ${ }^{1}$, Seong Kyu Moon ${ }^{1}$, , Mi Ji Lee ${ }^{2}$, and Seung Woo Kim ${ }^{1}(\mathbb{D}$ \\ ${ }^{1}$ Departments of Otorhinolaryngology-Head and Neck Surgery, ${ }^{2}$ Pathology, Veterans Health Service Medical Center, Seoul, Korea
}

반대측 부갑상선의 과증식증을 동반한 갑상선 내 부갑상선 암종 1 예

구범모 $^{1} \cdot$ 문성규 $^{1} \cdot$ 이미지 ${ }^{2} \cdot$ 김승우 ${ }^{1}$

중앙보훈병원 이비인후과, ${ }^{1}$ 병리과 ${ }^{2}$

Received March 6, 2021

Revised April 11,2021

Accepted April 14, 2021

Address for correspondence

Seung Woo Kim, MD

Department of Otolaryngology-

Head and Neck Surgery,

Veterans Health Service

Medical Center,

53 Jinhwangdo-ro 61-gil,

Gangdong-gu, Seoul 05368, Korea

Tel $+82-2-2225-1384$

Fax $+82-2-2225-1385$

E-mail entzzang1020@daum.net
Parathyroid carcinoma accounts for about $0.5 \%-5 \%$ of all parathyroid neoplasms. Very rarely, but if the intrathyroidal parathyroid gland is present, the carcinoma can arise in that developmental anomaly. It is very difficult to distinguish a thyroid nodule from an intrathyroidal parathyroid neoplasm with preoperative radiologic and cytologic evaluations. A 59-year-old male was initially evaluated as presenting a follicular thyroid neoplasm accompanied by hyperparathyroidism. He received hemi-thyroidectomy with central neck dissection and subtotal parathyroidectomy. The final pathology evaluation revealed intrathyroidal parathyroid carcinoma and hyperplasia of contralateral parathyroid glands. We report this very rare and unique clinical situation with a literature review.

Korean J Otorhinolaryngol-Head Neck Surg 2021;64(7):517-21

Key Words Hyperplasia · Parathyroid glands · Parathyroid neoplasms.

\section{서 론}

부갑상선 암종은 매우 드문 종양으로 40 50대에 호발하며, 전체 부갑상선 종양의 $0.5 \%$ 5\% 정도를 차지한다. ${ }^{1)}$ 부갑상선 은 경·흥부의 다양한 곳에 위치 할 수 있으며, 갑상선 내에 존재하는 경우는 $0.5 \%$ 4\% 정도로 매우 드물다. ${ }^{2)}$ 일반적으 로 술전 영상 평가 및 세침흡인검사 등으로 원발성 갑상선 종 물과 갑상선 내 부갑상선 종양을 감별하기는 매우 어렵다. ${ }^{3)}$ 부갑상선 항진증의 일차성 원인에는 과증식증 및 선종 등이 있고, 이차성은 만성 신질환에서 흔히 동반되는 부갑상선 과 증식증에 의해서 흔하게 발생한다. ${ }^{4}$

저자들은 부갑상선 기능항진증과 갑상선 종물로 내분비 내 과에서 의뢰된 만성 신부전을 가진 59세 남자 환자에서 좌측

This is an Open Access article distributed under the terms of the Creative Commons Attribution Non-Commercial License (https://creativecommons.org/licenses/by-nc/4.0) which permits unrestricted non-commercial use, distribution, and reproduction in any medium, provided the original work is properly cited.
갑상선 적출술, 중심 림프절 절제술 및 부갑상선 아전절제술 등을 시행하여, 갑상선 내 부갑상선 암종과 반대측 부갑상선 의 과증식증 등으로 진단된 증례를 경험하였다. 갑상선 내 부 갑상선 암종은 현재까지 국내에서 1 예의 보고가 있었으나, ${ }^{3)}$ 반대측에 부갑상선 과증식증을 동반한 암종은 보고가 없어 서, 문헌 고찰과 함께 보고하고자 한다.

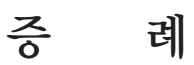

59세 남자 환자가 좌측 갑상선 결절의 초음파 유도하 세침 흡인검사에서 베데스다 분류 III 또는 IV로 평가되어, 진단적 수술을 위해 내분비내과에서 의뢰되었다. 기저질환으로 당뇨, 만성 신부전, 부신 기능 저하증 및 부갑상선 항진증 등이 있 었다. 경부에 비정상적으로 촉지되는 종물은 없었고, 신경학 적 검사에서도 정상 소견이었다. 갑상선 초음파에서 좌측 갑 상선의 중간에 고형의 $1.7 \times 1.8 \mathrm{~cm}$ 크기의 저에코성 종물이 
관찰되었다(Fig. $1 \mathrm{~A}$ and B). 비조영증강 경부 전산화단층촬 영에서 좌측 갑상선의 중간 부위에 석회화를 동반한 타원형 의 $2.1 \times 1.9 \mathrm{~cm}$ 크기의 종물이 관찰되었다(Fig. $1 \mathrm{C}$ ). 갑상선 기능검사, 총 칼슘 및 이온화 칼슘, 인, 마그네슘 및 알부민 등 은 모두 정상 범위였으나, 부갑상선 호르몬(intact parathyroid hormone, iPTH)은 $228 \mathrm{pg} / \mathrm{mL}$ (참고값: 15 65)로 크게 증가된 소견이었다. 혈중요소질소는 $55 \mathrm{mg} / \mathrm{dL}$ (참고값: 8 24), 크레아티닌 $2.9 \mathrm{mg} / \mathrm{dL}$ (참고값: 0.6 1.0), 사구체여과율(estimated glomerular filtration rate)은 $6 \mathrm{~mL} / \mathrm{min} / 1.73 \mathrm{~m}^{2}$ (참 고값: 60 이상) 등으로 만성 신부전에 합당한 소견이었다. 부 갑상선의 기능 평가를 위하여 시행한 ${ }^{99 \mathrm{~m}} \mathrm{Tc}-$ sestamibi 스캔 에서는 특이 소견 없었다(Fig. 1D).

이상의 결과 등을 종합해서 좌측 갑상선 여포성 종양 및 만성 신부전에 병발된 이차성 부갑상선 항진증의 가능성을 우선적으로 고려하고, 좌측 갑상선 절제술, 중심림프절 절제 술 및 부갑상선 아전절제술 등을 계획 하였다. 반회유두신경 감시술 하에서 먼저 우측 갑상선의 측면을 박리하여 상부 및 하부 부갑상선을 노출시키고, 반회유두신경 확인 후 우측 상 하부 부갑상선을 적출하였다. 특히 상부 부갑상선의 크기가
매우 증가돼 있었고, 딱딱한 성상이었다. 좌측도 우측과 같 은 방법으로 우측 부갑상선이 있던 위치와 대칭되는 곳에서 가장 커져 있고, 부갑상선과 최대한 유사한 성상으로 보이는 종물들을 적출하였다. 좌측 하방 종물은 상부의 절반을 제 거하고, 나머지는 보존하였다(Fig. 2). 이어서 좌측 갑상선 절 제술과 중심림프절 절제술 등을 시행하였고, 이때 좌측 갑상 선의 측면 중간 부위에 딱딱한 종물이 촉지되었고, 이 부분 이 흥골갑상근 및 갑상선 주변 조직 등과 유착이 있었다 (Fig. 2). 동결절편검사는 시행하지 않았고, 수술 직후에 마취 회복실에서 시행한 $\mathrm{iPTH}$ 는 $26.65 \mathrm{pg} / \mathrm{mL}$ (참고값: 15 65)로 급격히 감소하였다. 술후 음성 변화, 사지 저림 등의 증상은 없었다.

병리 육안 소견에서 좌측 갑상선의 종물은 중간 내부에 위 치하며 주변 갑상선 조직과 확연히 구분되는 절단면이 노란 색인 $1.8 \times 1.3 \mathrm{~cm}$ 의 크기였으며(Fig. $3 \mathrm{~A}$ and B), 우측 상부의 부갑상선 종물은 선홍색 구형이었다(Fig. $3 \mathrm{C}$ ). 현미경 소견에 서는 좌측 갑상선 종물은 주변 조직을 침범하는 양상이었고, 여포 종양과의 감별을 위해 면역화학염색을 시행하였다. 티 로글로불린 및 thyroid transcription factor-1 염색 등에서
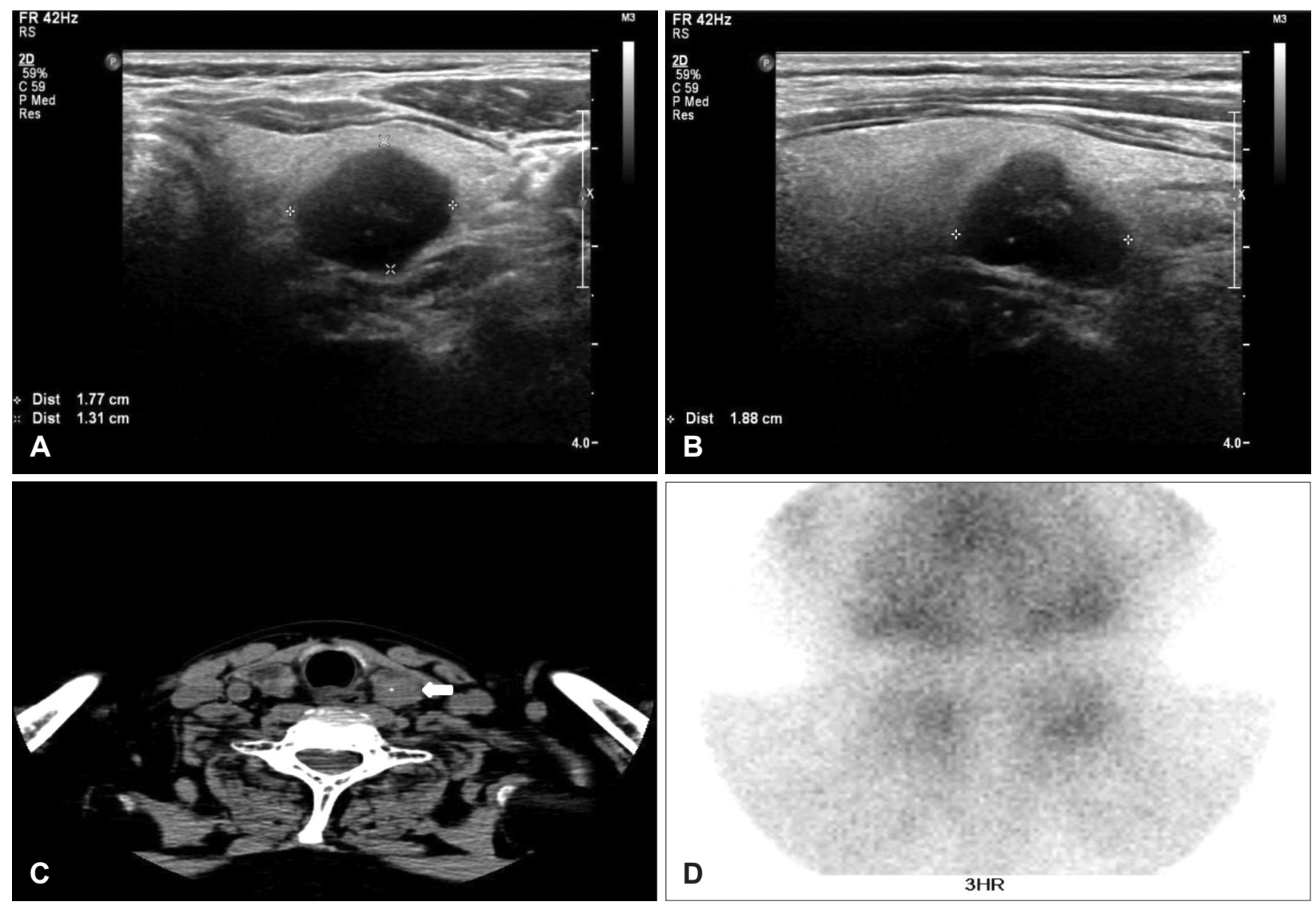

Fig. 1. Preoperative imaging studies. Transverse scans of neck ultrasonography show hypoechoic nodules, $1.7 \times 1.3 \times 1.8 \mathrm{~cm}$ sized mass on posterior aspect of left thyroid gland (A) and (B) (asterisks), and the non-enhanced axial neck CT scans show $2.1 \times 1.9 \mathrm{~cm}$ sized ovoid mass including calcification (arrow) (C), and the three hours' image of ${ }^{99 \mathrm{~m} T c-s e s t a m i b i}$ scan shows no abnormal finding (D). 
음성, cytokeratin 7과 GATA-3 염색 등에서 양성을 보여서 갑상선 내 부갑상선 암종으로 진단되었고(Fig. $4 \mathrm{~A}, \mathrm{~B}$, and $\mathrm{D}-\mathrm{G})$, 우측 부갑상선은 상하부 모두 과증식증으로 진단되었 다(Fig. 4 C). 좌측 부갑상선 종물로 생각되어 적출한 조직들 은 모두 섬유성 지방조직으로 진단되었다.

최종 병리 진단 이후에 내분비내과, 신장내과 및 병리과 등 과 합동 회의를 진행하였다. 여기서 저자들은 "술전에 부갑상 선 호르몬 증가의 원인으로 만성 신부전을 동반하고 있어, 먼저 이차성 부갑상선 항진증을 의심하였으며, 만약 이런 기 저 질환이 없었다면 우선적으로 부갑상선 종양을 고려했었 을 것 같다."는 의견을 제시하였다. 부갑상선 항진증의 원인에 대한 내과 의견은 만성 신부전이 주 원인으로 보이지만, 부갑 상선 암종에 의한 호르몬 과분비의 가능성도 있다는 소견이 었다. 환자는 술후 5 일에 특별한 합병증 없이 퇴원하였고, 수 술 후 1년이 지난 현재까지 초음파 추에서 재발 소견 없으며, 부갑상선 호르몬도 정상범위를 유지하며 추적 관찰 중이다.

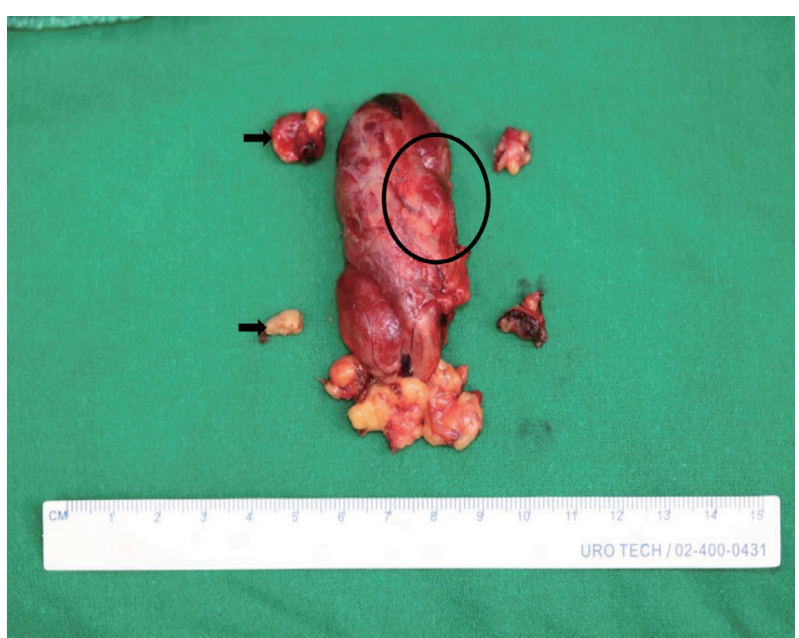

Fig. 2. The photo of the extract immediately after surgery. The black circled area of left thyroid means intrathyroidal parathyroid carcinoma, and two black arrows show right superior and inferior parathyroid hyperplasia.

\section{고 찰}

발생학적으로 상부 부갑상선의 경우 주로 갑상선 후측방에 위치하지만, 하부 부갑상선은 발생학적 과정상 그 위치가 다 양하며, 이소성 부갑상선도 존재 할 수 있다. ${ }^{5)}$ 이 중 갑상선 내 부갑상선은 주변이 갑상선 조직으로 완전히 둘러 쌓여져 있는 경우로 정의되며, 발생 빈도는 $0.5 \%$ 4\%로 드물다. ${ }^{6.7)}$ 갑 상선 내 부갑상선의 기원에 대해서는 상부, 하부 및 과수 부 갑상선 기원 등 여러 의견이 있으나, 아직 완전히 정립되지 않 았다. ${ }^{8)}$ 본 증례는 최종 병리 결과에서 좌측 부갑상선으로 예 상하고 적출한 종물은 모두 지방조직으로, 또 좌측 갑상선은 부갑상선 암종으로 진단되고, 부갑상선 호르몬은 수술 직후 에 정상으로 조절되었다. 이러한 결과를 유추해 보면 상부 부 갑상선은 그대로 잔존해 있을 가능성이 있고, 하부 부갑상선 이 갑상선 내에 위치했던 것으로 추정해 볼 수 있다.

부갑상선 암은 모든 암종의 $0.005 \%$ 정도를 차지하는 매우 드문 암으로, 이 중 $90 \%$ 는 부갑상선 호르몬을 분비하는 기 능성 종양이며, 비 기능성은 $10 \%$ 정도로 드물다. ${ }^{9)}$ 갑상선 내 부갑상선에 선종, 과증식증 및 암종 등이 모두 발생할 수 있 으며, ${ }^{8}$ 갑상선 내 부갑상선 암은 현재까지 15예 정도 보고되 어 있으며, 이 중 국내 보고는 1예이다. ${ }^{3)}$ 이러한 증례들은 대 부분 기능성 암종으로 고칼슘혈증과 혈중 부갑상선 호르몬 이 $200 \mathrm{pg} / \mathrm{mL}$ 이상으로 증가되어 있었다.) 본 증례는 혈액 칼슘 및 인은 정상 범위이고, 부갑상선 호르몬만 증가되어 있 었다. 술후 여러 임상과와의 회의에서는 부갑상선 항진증의 원인에 대해서 만성 신부전에 의한 이차성 항진증이 주 원인 으로 보이지만, 부갑상 암종의 영향도 배제할 수 없다는 의 견이었다.

부갑상선 병변의 위치를 특정하기 위한 검사로는 초음파, 핵의학 검사 및 전산화단층촬영 등이 있으며, 이들 검사의 민감도는 부갑상선 질환의 종류와 보고자에 따라서 차이가 있지만, 대부분 $80 \%$ 이상으로 알려져 있다. ${ }^{10)}$ 본 증례에서는
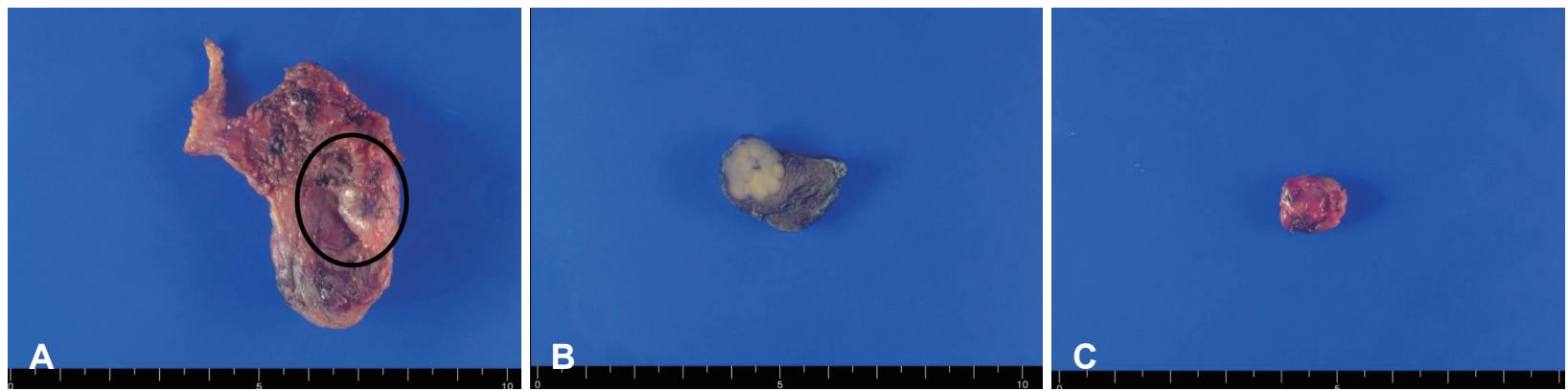

Fig. 3. The gross specimens. (A) is extracted left thyroid gland and the intrathyroidal mass is marked with a black circle. (B) is horizontal cutting at mid-level of left thyroid (black circled portion), and it shows pale yellowish and firm mass. (C) is right upper parathyroid mass. 

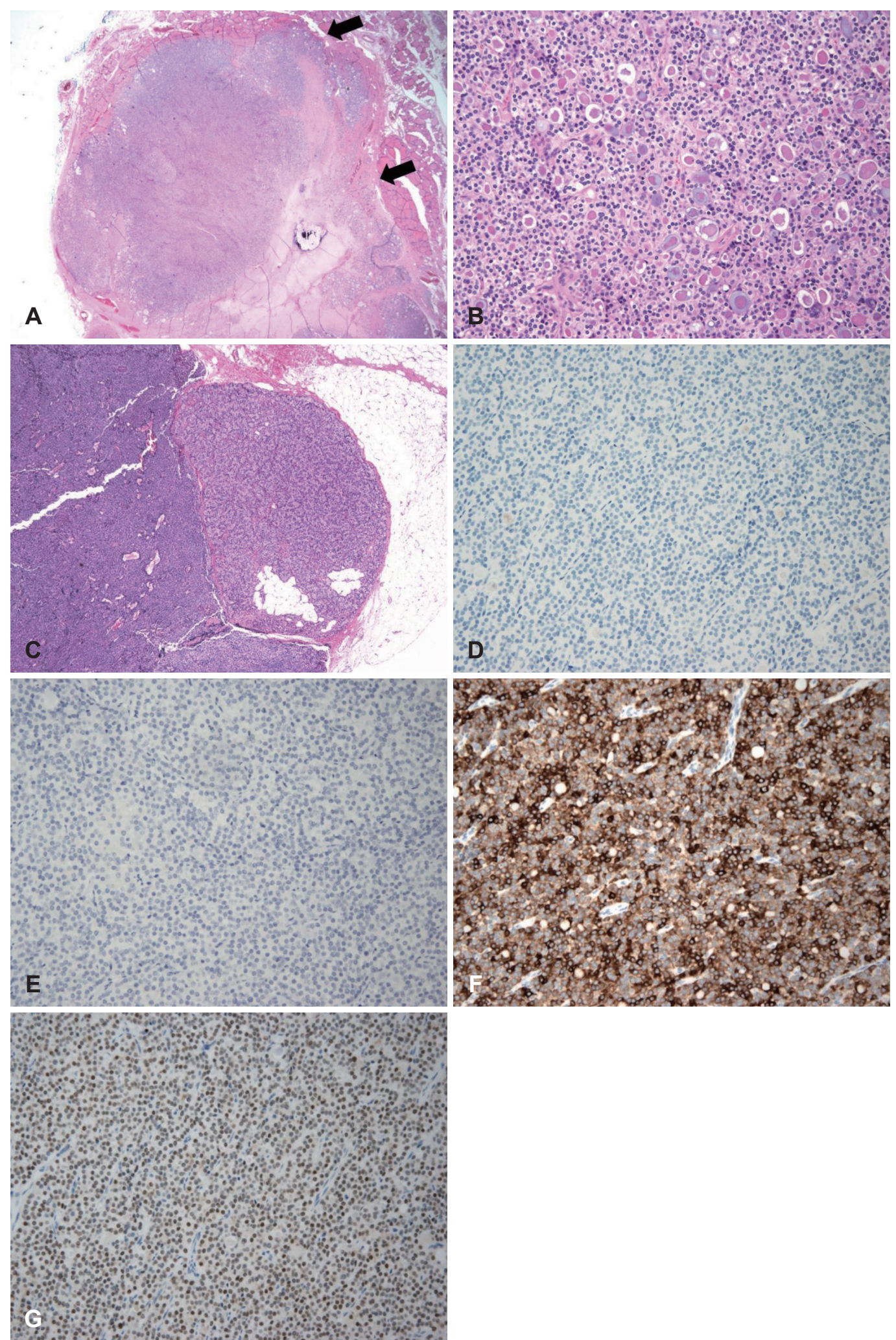

Fig. 4. The pathological findings. The tumor shows solid growth pattern and invades adjacent thyroidal parenchyma $($ arrows, H\&E, $\times 25)$ (A). Due to uniform tumor cells with colloid-like material, it is difficult to differentiate between follicular thyroid neoplasm and parathyroid neoplasm based on the histology $(H \& E, \times 200)(B)$. It shows contralateral parathyroid hyperplasia $(H \& E, \times 25)(C)$. The immunohistochemical findings. The tumor cells are negative for thyroglobulin (D) and thyroid transcription factor-1 (E), which suggest non-thyroidal origin tumor. And the immunopositivity for cytokeratin 7 (F) and GATA-3 (G) support that the tumor is parathyroid neoplasm ( $\times 200)(D-G)$. H\&E: hematoxylin and eosin. 
우측 부갑상선의 과증식증과 좌측 갑상선 내 부갑상선 암종 등이 있었지만, ${ }^{99 \mathrm{~m}} \mathrm{Tc}-$ sestamibi 스캔에서 이상 소견이 없었 다. 이런 경우 단일광자 방출 컴퓨터단층촬영(single photon emission computed tomography)을 시행하면, 부갑상선 질 환의 진단에 도움이 된다는 보고도 있다. ${ }^{11)}$ 여포상 종물과 갑 상선 내 부갑상선에 발생한 종물을 구별하는 것은 매우 어려 워서, 본 증례에서도 갑상선 여포상 종물로 평가되었고, 보고 된 유사 증례 중에서 술전에 세침흡인검사를 시행한 7예 중 부갑상선 병변으로 진단된 것은 단 2예 였다. ${ }^{3}$ 부갑상선의 과 증식증, 선종 및 암종 등의 감별에는 면역화학검사가 주로 필 요해서, 술전 세침흡인검사, 중심생검 및 동결절편 검사 등으 로는 진단이 어렵다. ${ }^{12)}$

비기능성 부갑상선 암종은 주로 무증상이며, 조기 발견이 어려워서, 기능성 암종보다 예후가 불량할 수 있다.") 임상적으 로 부갑상선 암의 의심되는 상황에서 갑상선 내 부갑상선 암 종은 여포성 종물로 잘 오인 되며, 술중 동결절편 검사로도 감별 진단이 어려워서, 갑상선 결절 있는 경우 동측의 갑상선 절제술을 같이 시행하는 것이 추천된다. ${ }^{3)}$ 갑상선 내 부갑상선 암종은 수술이 주된 치료이며, 일반적으로 부갑상선과 동측 갑상선, 기관주위 림프절 등을 같이 제거한다. ${ }^{13)}$ 갑상선 외 부 갑상선 암과의 예후 비교에 대해서는 아직 보고된 바가 없다.

본 증례를 통하여 영상학적으로 일차성 갑상선 종양으로 진단되었어도, 매우 드물지만 갑상선 내 부갑상선에 종물이 존재 할 수 있으며, 이런 경우는 진단적 갑상선 절제술을 시 행해야 최종 진단이 가능하다는 교훈을 얻었다. 향후 다기관 연구를 통한 갑상선 내 부갑상선 암종의 유사 증례를 채집하 여, 술전 진단, 임상적 특징, 표준 치료 및 예후 등에 관한 전 향적인 연구가 필요할 것으로 사료된다.

\section{Acknowledgments}

None.

\section{Author Contribution}

Conceptualization: Seung Woo Kim. Data curation: Seong Kyu Moon. Formal analysis: Beom Mo Koo. Investigation: Beom Mo Koo. Methodology: Seong Kyu Moon. Supervision: Seung Woo Kim. Validation: Mi Ji Lee. Visualization: Mi Ji Lee. Writingoriginal draft: Beom Mo Koo, Seung Woo Kim. Writing—review \& editing: Seung Woo Kim.

\section{ORCIDs}

Seung Woo Kim https://orcid.org/0000-0002-7931-6977

Beom Mo Koo https://orcid.org/0000-0002-2597-1204

Seong Kyu Moon https://orcid.org/0000-0001-6690-2769

\section{REFERENCES}

1) Wynne AG, van Heerden J, Carney JA, Fitzpatrick LA. Parathyroid carcinoma: Clinical and pathologic features in 43 patients. Medicine (Baltimore) 1992;71(4):197-205.

2) Herden U, Seiler CA, Candinas D, Schmid SW. Intrathyroid adenomas in primary hyperparathyroidism: Are they frequent enough to guide surgical strategy? Surg Innov 2011;18(4):373-8.

3) Kim MK, Song CM, Tae K, Ji YB. Intrathyroidal parathyroid carcinoma in chronic kidney disease: A case report and review of literature. Korean J Otorhinolaryngol-Head Neck Surg 2019; 62(12):740-6.

4) Im JH, Kim DH, Choi SH, Kim YM. Multiple nonfunctioning parathyroid carcinoma secondary to chronic renal failure. Korean J Otolaryngol 2003;46(6):532-5.

5) Choi JY, Yoo HJ, Park YH, Cho SH. A case of spontaneous extracapsular hemorrhage of intrathyroidal parathyroid adenoma. Korean J Otorhinolaryngol-Head Neck Surg 2010;53(4):245-7.

6) Bahar G, Feinmesser R, Joshua BZ, Shpitzer T, Morgenstein S, Popovtzer A, et al. Hyperfunctioning intrathyroid parathyroid gland: A potential cause of failure in parathyroidectomy. Surgery 2006; 139(6):821-6.

7) McIntyre RC Jr, Eisenach JH, Pearlman NW, Ridgeway CE, Liechty RD. Intrathyroidal parathyroid glands can be a cause of failed cervical exploration for hyperparathyroidism. Am J Surg 1997; 174(6):750-3; discussion 753-4.

8) Harach HR, Vujanić GM. Intrathyroidal parathyroid. Pediatr Pathol 1993;13(1):71-4.

9) Goswamy J, Lei M, Simo R. Parathyroid carcinoma. Curr Opin Otolaryngol Head Neck Surg 2016;24(2):155-62.

10) Lee SW, Park H, Shin JM, Lee YM, Park JH, Koh YW, et al. Clinical analysis of parathyroid adenoma with primary hyperparathyroidism. Korean J Otolaryngol 2006;49(1):72-8.

11) Yeh R, Tay YD, Tabacco G, Dercle L, Kuo JH, Bandeira L, et al. Diagnostic performance of 4D CT and sestamibi SPECT/CT in localizing parathyroid adenomas in primary hyperparathyroidism. Radiology 2019;291(2):469-76.

12) Kang JH, Choi KM, Kim YJ, Kim SW. A Case of non-functioning parathyroid carcinoma with cystic change and internal hemorrhage. J Korean Thyroid Assoc 2009;2(2):144-7.

13) Murphy MN, Glennon PG, Diocee MS, Wick MR, Cavers DJ. Nonsecretory parathyroid carcinoma of the mediastinum. Light microscopic, immunocytochemical, and ultrastructural features of a case, and review of the literature. Cancer 1986;58(11):2468-76. 